\title{
TRITERPENES AND NEW SAPONINS FROM Ilex chamaedryfolia: CHEMOTAXONOMIC TOOL TO Ilex SPECIES DIFFERENTIATION
}

\author{
Claiton L. Lencina, Mariana C. de Cardoso, Ivomar Zancanaro e Grace Gosmann* \\ Faculdade de Farmácia, Universidade Federal do Rio Grande do Sul, Av. Ipiranga, 2752, 90610-000 Porto Alegre - RS, Brasil \\ Viviane S. Pires, Pascal Sonnet e Dominique Guillaume ${ }^{\#}$ \\ UMR-CNRS 6219, Laboratoire des glucides, Faculté de Pharmacie, Université de Picardie Jules Verne, 1 rue des Louvels, 80037 \\ Amiens, France \\ Eloir P. Schenkel \\ Centro de Ciências da Saúde, Universidade Federal de Santa Catarina, 88040-900 Florianópolis - SC, Brasil
}

Recebido em 16/2/10; aceito em 13/9/10; publicado na web em 8/12/10

\begin{abstract}
Three saponins were isolated from leaves of Ilex chamaedryfolia. Their structures were established by spectroscopic and mass

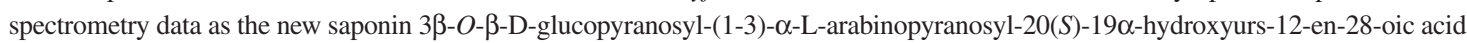
$28-O$ - $\beta$-D-glucopyranosyl-(1-3)- $\beta$-D-glucopyranosyl ester, the new saponin 3 $\beta$ - $O-\beta$-D-glucopyranosyl-(1-3)- $\alpha$-L-arabinopyranosyl$20(S)$-19 $\alpha$-hydroxyurs-12-en-28-oic acid 28- $O$ - $\beta$-D-glucopyranosyl ester and the known saponin 3 $\beta$ - $O$ - $\beta$-D-glucuronopyranosyl20(R)-19 $\alpha$-hydroxyurs-12-en-28-oic acid 28- $O$ - $\beta$-D-glucopyranosyl ester. Ursolic acid and $\alpha$-amyrin were also isolated.
\end{abstract}

Keywords: Ilex chamaedryfolia; Aquifoliaceae; triterpenes.

\section{INTRODUCTION}

We initiated some years ago a program aimed to identified saponins from South American Ilex species ${ }^{1}$ considering the importance of this genera which includes Ilex paraguariensis A. St. Hil., named yerba mate. This species is widely used in South Brazil, Argentina, Paraguay and Uruguay to obtain the raw material used to prepare the traditional beverage called mate which is a very important economical crop. Hence, we already reported the structure of several saponins isolated from maté and other South American Ilex species: I. affinis. I. argentina. I. brevicuspis. I. buxifolia. I. dumosa. I. integerrima. I. microdonta. I. psammophila. I. pseudobuxus. I. taubertiana and I. theezans. ${ }^{1-8}$

Ilex chamaedryfolia Reissek is a native shrub in Southern Brazil, found in the states of Rio Grande do Sul, Paraná and Santa Catarina, where it is known as "congonha miúda", "congonhinha" or "congonha brava". ${ }^{2,9}$ I. chamaedryfolia is one of the species eventually reported as an adulterant of the I. paraguariensis. Herein it is described the isolation and structural elucidation of three saponins and two triterpenes (ursolic acid and $\alpha$-amyrin) from the leaves of I. chamaedryfolia. As far as we know, the saponins reported herein have not been yet described in the literature.

\section{EXPERIMENTAL}

\section{Plant material}

Leaves from I. chamaedryfolia Reissek were collected in Guaratuba, State of Paraná, Brazil. A specimen is on deposit in the Herbarium of the Department of Botany (ICN) at the Universidade

*e-mail: grace.gosmann@ufrgs.br

"Present address: Faculté de Pharmacie, Université de Reims, Chimie Thérapeutique, 51 rue Cognacq Jay, 51100 Reims, France
Federal do Rio Grande do Sul, Porto Alegre, Brazil (M. Sobral and E. P. Santos 9308).

\section{General}

Optical Rotation was measured on a Perkin-Elmer ${ }^{\circledR} 341$ polarimeter. FAB-MS analysis was performed in positive mode on a Kratos MS 80 instrument and HRMS MS spectra were recorded on a Q-Tof micro Waters ${ }^{\circledR}$ high resolution mass spectrometer, operating on eletronspray ionization mode. NMR spectra $\left({ }^{1} \mathrm{H}, 500 \mathrm{MHz} ;{ }^{13} \mathrm{C}, 125 \mathrm{MHz}\right)$ were recorded in $\mathrm{CD}_{3} \mathrm{OD}$ and $\mathrm{CDCl}_{3}$ on a Bruker ${ }^{\circledR}$ Avance 500 spectrometer. Thin-layer chromatography (TLC) was on $\mathrm{Si}$ gel $\mathrm{GF}_{254}$ Merck or Aldrich ${ }^{\circledR}$ using $\mathrm{CH}_{2} \mathrm{Cl}_{2}: \mathrm{MeOH}(98: 2, \mathrm{v} / \mathrm{v})$ and $\mathrm{CHCl}_{3}: \mathrm{MeOH}: \mathrm{H}_{2} \mathrm{O}$ $(80: 40: 5, \mathrm{v} / \mathrm{v})$ as eluents for sapogenins and saponins, respectively. Compounds were visualised using anysaldehyde-sulphuric acid reagent and heating $\left(100{ }^{\circ} \mathrm{C}\right)$.

\section{Extraction and isolation}

Air-dried powdered leaves ( $475 \mathrm{~g}$ ) were submitted to maceration in aqueous $80 \% \mathrm{EtOH}(1: 10$ plant:solvent, $\mathrm{m} / \mathrm{v})$ at room temperature ( 2 x 10 days). The ethanol extract was evaporated to dryness under reduced pressure and the residue $(85 \mathrm{~g}, 18 \%)$ was suspended in water $(1500 \mathrm{~mL})$ and extracted successively with dichloromethane $(3 \times 500$ $\mathrm{mL})$, ethyl acetate ( $3 \times 500 \mathrm{~mL})$ and $n$-butanol $(3 \times 500 \mathrm{~mL})$. Each organic phase was separately evaporated to obtain $5 \mathrm{~g}(0.7 \%), 5 \mathrm{~g}$ $(0.7 \%)$ and $45 \mathrm{~g}(9.5 \%)$ of each fraction, respectively. The aqueous residue was lyophilised to obtain $27 \mathrm{~g}(5.6 \%)$.

Dichloromethane fraction ( $1 \mathrm{~g}$ ) was submitted to CC on silica gel eluting with gradients of ciclohexane:ethyl acetate mixtures. Fractions were pooled according to TLC. Fractions 35-41 (88 mg) and 82-85 $(30 \mathrm{mg})$ were subjected to crystallisation in yielding compounds $\mathbf{1}(19 \mathrm{mg})$ and $\mathbf{2}(25 \mathrm{mg})$ in a pure form, respectively. Part of the $n$-butanol fraction (10 g) was submitted to successive $\mathrm{CC}$ on silica 
gel eluting with gradients of $\mathrm{CH}_{2} \mathrm{Cl}_{2}: \mathrm{EtOH}: \mathrm{H}_{2} \mathrm{O}$ mixtures, or $\mathrm{CC}$ on LiChroprep $^{\mathrm{TM}} \mathrm{RP}-18$ using $\mathrm{H}_{2} \mathrm{O}: \mathrm{MeOH}$. Fractions were pooled according to their TLC profiles. Compounds $\mathbf{3}(13 \mathrm{mg}), \mathbf{4}(10 \mathrm{mg})$ and $5(13 \mathrm{mg}$ ) were isolated (Figure 1). One fraction containing mainly compound $\mathbf{3}$ was acetylated ${ }^{6}$ to obtain pure $\mathbf{3 a}(14 \mathrm{mg})$.

$\alpha$-amyrin (1). This compound was identified after comparison of its physical-chemical data with the literature ${ }^{10}$ and by co-TLC with an authentic sample.

Ursolic acid (2). (3ß)-3-hydroxyurs-12-en-28-oic acid. It was identified by co-TLC with an authentic sample. ${ }^{11}$

Compound $\mathbf{3}$ was identified as the deacylated form of $\mathbf{3 a}$ after comparison of both NMR data.

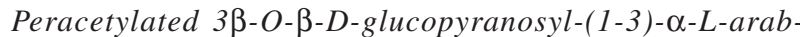
inopyranosyl-20(S)-19 $\alpha$-hydroxyurs-12-en-28-oic acid 28-O- $\beta$-Dglucopyranosyl-(1-3)- $\beta$-D-glucopyranosyl ester (3a). Amorphous powder. FABMS (positive mode) $\mathrm{m} / \mathrm{z}: 1659[\mathrm{M}+\mathrm{Na}]^{+}$and HRMS $m / z, 1659.7831[\mathrm{M}+\mathrm{Na}]^{+}\left(\mathrm{C}_{79} \mathrm{H}_{112} \mathrm{O}_{36}\right) .[\alpha]^{25}{ }_{\mathrm{D}}+14.3^{\circ}\left(\mathrm{CHCl}_{3}, c 0.35\right)$. ${ }^{1} \mathrm{H}$ NMR and ${ }^{13} \mathrm{C}$ NMR data $\left(\mathrm{CDCl}_{3}\right)$ : see Table 1 .

$3 \beta$-O- $\beta$-D-glucopyranosyl-(1-3)- $\alpha$-L-arabinopyranosyl-20(S)$19 \alpha$-hydroxyurs-12-en-28-oic acid 28-O- $\beta$-D-glucopyranosyl ester (4). Amorphous powder. FABMS (positive mode) $\mathrm{m} / \mathrm{z}: 951$ and $\mathrm{HRMS} \mathrm{m} / \mathrm{z}$ $951.4899[\mathrm{M}+\mathrm{Na}]^{+}\left(\mathrm{C}_{47} \mathrm{H}_{76} \mathrm{O}_{18}\right) \cdot[\alpha]^{25}{ }_{\mathrm{D}}-1.67^{\circ}(\mathrm{MeOH}, c 0.6) .{ }^{1} \mathrm{H} \mathrm{NMR}$ and ${ }^{13} \mathrm{C}$ RMN data $\left(\mathrm{CD}_{3} \mathrm{OD}\right)$ : see Table 1 .

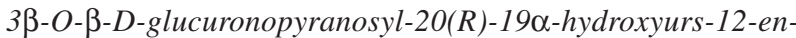
28 -oic acid 28-O- $\beta$ - $D$-glucopyranosyl ester (5). Amorphous powder. FABMS (positive mode) $\mathrm{m} / \mathrm{z}: 833.6[\mathrm{M}+\mathrm{Na}]^{+} .{ }^{1} \mathrm{H} \mathrm{NMR}$ and ${ }^{13} \mathrm{C} \mathrm{NMR}$ data $\left(\mathrm{CD}_{3} \mathrm{OD}\right)$ : see Table 1 .

\section{RESULTS AND DISCUSSION}

Solvent partition and chromatographic procedures allowed the isolation of five compounds from leaves of I. chamaedryfolia whose identification was accomplished through spectroscopic methods.

Compound 1 was identified as $\alpha$-amyrin after comparison of its physical-chemical data with literature and by co-TLC with an authentic sample. Compound $\mathbf{2}$ was rapidly identified as ursolic acid by co-TLC analysis using authentic sample.

Along with the signals corresponding to acetyl groups, $\left\{{ }^{1} \mathrm{H}\right\}-{ }^{13} \mathrm{C}$ NMR spectrum of 3a showed 53 signals, which after comparison with its DEPT- ${ }^{13} \mathrm{C}$-NMR spectrum, allow to recognize signals attributed to 7 methyl, 13 methylene and 25 methine groups, and 8 quaternary carbon atoms. The ${ }^{13} \mathrm{C}-\mathrm{NMR}$ of this compound showed characteristic signals due to one carboxyl group $(\delta 175.7)$, a double bond $(\delta 128.0 ; \delta$ $137.0)$ and two oxygenated carbons $(\delta 72.9 ; \delta 89.9)$ beyond the acetyl characteristic signals. ${ }^{12}$ A signal at $\delta_{\mathrm{H}} 2.77(s, 1 \mathrm{H}, \mathrm{H}-18)$ suggesting the presence of a 19-O-substituted urs-12-en skeleton, specifically a $19 \alpha$-hydroxyursolic acid derivative. ${ }^{13}$ Chemical shifts of the C-18, C-22 and C-23 were found at upfield shift and indicate an unusual 20 $S$ configuration to E ring of aglycone (Table 1). ${ }^{8,12}$ The observation of chemical shifts to C-28 $(\delta 175.7)$ and C-3 $(\delta 89.9)$ dislocated to upfield and downfield respectively, cleared bisdesmosidic features. Thus, the compound $\mathbf{3 a}$ (and $\mathbf{3}$ ) has as aglycone ilexgenin B (Figure 1). ${ }^{12}$

Its ${ }^{1} \mathrm{H}-\mathrm{NMR}$ and ${ }^{13} \mathrm{C}-\mathrm{NMR}$ data indicated the presence of four sugar moieties. The sugar residue $\delta_{\mathrm{H}} 5.55\left(\mathrm{H}-1\right.$ '"'); $\delta_{\mathrm{C}} 91.7(\mathrm{C}-1$ "'”) evidenced an ester linkage between the anomeric carbon and the $\mathrm{C}-28$ of the aglycone. ${ }^{14}$ For the sugar chain, $\mathrm{HH}$ and $\mathrm{HC}$ correlation (COSY, HMQC, HMBC) (Figure 2) allowed to assign all carbon and proton signals. HMBC correlation spectrum allowed indicated the interglycosidic linkages, between the terminal glucose $\left(\delta_{\mathrm{H}} 4.73, \mathrm{H}-1 ; \delta_{\mathrm{C}} 99.7\right.$, C-1), attached at C-3"' of glucose II at C-28, as well as, glucose I and arabinose unit substituted at $\mathrm{C}-3$. This spectrum showed a correlation between C-3' of arabinose and H-1" of glucose I, C-3"' of glucose II and $\mathrm{H}-1$ "' " of glucose III (Figure 2). Besides H-1' of arabinose and C-3 of aglycone, $\mathrm{H}-1$ "' of glucose II and C-28 of aglycone. Thus 3a was identified to be peracetylated form of $3 \beta-O-\beta-\mathrm{D}$-glucopyranosyl-(13)- $\alpha$-L-arabinopyranosyl-20(S)-19 $\alpha$-hydroxyurs-12-en-28-oic acid

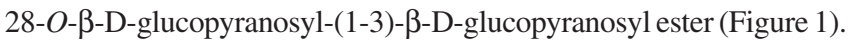
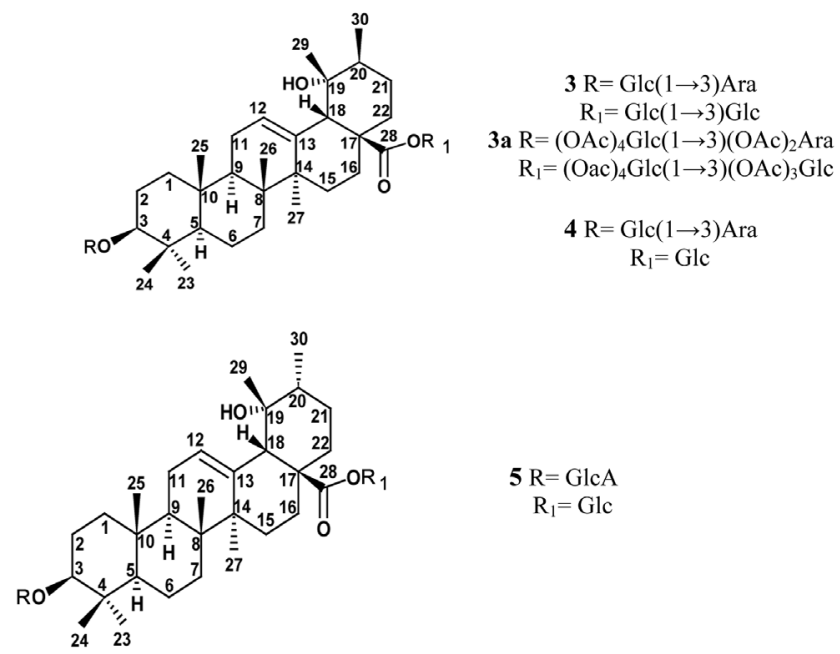

$5 \mathrm{R}=\mathrm{GlcA}$

$\mathrm{R}_{1}=\mathrm{Glc}$

Figure 1. Compounds 3, 4 and 5 isolated from leaves of Ilex chamaedryfolia
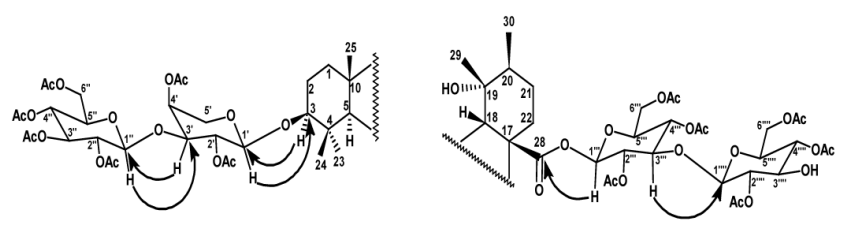

$3 \mathbf{a}$
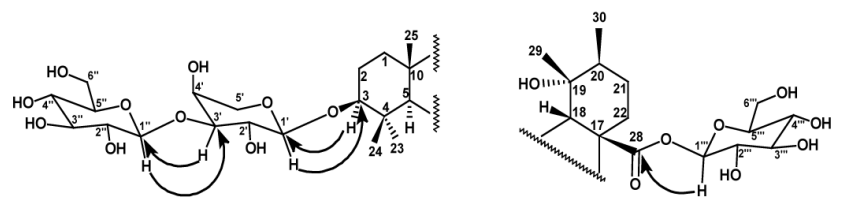

4

Figure 2. Main long range correlations observed in HMBC spectra for 3 a and 4

Comparative analysis of the ${ }^{13} \mathrm{C}-\mathrm{NMR}-\left\{{ }^{1} \mathrm{H}\right\}$ and ${ }^{13} \mathrm{C}-\mathrm{NMR}-$ DEPT spectra of $\mathbf{4}$ was also used to identify the presence of signals attributed to 7 methyl, 12 methylene and 20 methine groups and 8 quaternary carbon atoms. The NMR data $\left({ }^{13} \mathrm{C} ;{ }^{1} \mathrm{H}\right)$ of compound $\mathbf{4}$ were very similar to compound $\mathbf{3 a}$ excepting the absence of the acetyl characteristic signals and those corresponding to one glucose. After detailed analysis of the spectroscopic data of $\mathbf{4}$ it was possible to conclude that this compound contained a single glucose residue in the ester chain at $\mathbf{C}-28$, contrasting to $\mathbf{3} \mathbf{a}$ and $\mathbf{3}$ that contained two glucose units. Thus, 4 was identified as $3 \beta-O-\beta$-D-glucopyranosyl(1-3)- $\alpha$-L-arabinopyranosyl-20(S)-19 $\alpha$-hydroxyurs-12-en-28-oic acid 28-O- $\beta$-D-glucopyranosyl ester (Figure 1). The $\mathrm{HH}$ and $\mathrm{HC}$ correlation (COSY, HMQC and HMBC) allowed to assign all carbon and proton signals and to identify all interglycosidic linkages (Figure 2 ). The $20 R$ enantiomer of this compound has already been reported 
Table 1. ${ }^{1} \mathrm{H}$ and ${ }^{13} \mathrm{C}$ NMR spectral data for triterpenoids $\mathbf{3 a}, \mathbf{4}$ and $\mathbf{5}$ compared to literature

\begin{tabular}{|c|c|c|c|c|c|c|c|}
\hline & \multicolumn{2}{|c|}{$\mathbf{3 a}, \mathrm{CDCl}_{3}$} & \multicolumn{2}{|c|}{$4, \mathrm{CDCl}_{3}$} & \multirow{2}{*}{$\begin{array}{c}\mathbf{5}, \mathrm{CD}_{3} \mathrm{OD} \\
\delta_{\mathrm{C}} \\
\end{array}$} & \multicolumn{2}{|c|}{ Mo- $1, \mathrm{CD}_{3} \mathrm{OD}$} \\
\hline & $\delta_{\mathrm{C}}$ & $\delta_{\mathrm{H}}$ & $\delta_{\mathrm{C}}$ & $\delta_{\mathrm{H}}$ & & $\delta_{\mathrm{C}}$ & $\delta_{\mathrm{H}}$ \\
\hline $\mathrm{CH}_{2}-1$ & 38.6 & & 38.5 & & 39.9 & 39.90 & $1.64,0.99$ \\
\hline $\mathrm{CH}_{2}-2$ & 26.0 & & 25.8 & & 21.1 & 27.05 & $1.84,1.73$ \\
\hline $\mathrm{CH}-3$ & 89.9 & $3.10(\mathrm{~m})$ & 89.2 & $3.10(\mathrm{~m})$ & 90.9 & 90.56 & $3.15(\mathrm{dd}, 11.5,4.0)$ \\
\hline C-4 & 39.9 & & 38.8 & & 40.2 & 40.20 & \\
\hline CH-5 & 55.6 & & 55.7 & & 57.0 & 57.03 & 0.79 \\
\hline $\mathrm{CH}_{2}-6$ & 18.2 & & 18.0 & & 19.4 & 19.44 & 1.53 \\
\hline $\mathrm{CH}_{2}-7$ & 33.0 & & 32.8 & & 34.2 & 34.14 & $1.54,1.33$ \\
\hline C-8 & 39.2 & & 39.8 & & 42.7 & 41.23 & \\
\hline CH-9 & 47.1 & & 47.8 & & 48.0 & 48.59 & 1.67 \\
\hline $\mathrm{C}-10$ & 36.6 & & 38.8 & & 37.8 & 37.84 & \\
\hline $\mathrm{CH}_{2}-11$ & 23.8 & & 23.3 & & 24.6 & 24.73 & 1.97 \\
\hline $\mathrm{CH}-12$ & 128.0 & 5.35 (br s) & 127.5 & $5.15(\mathrm{br} \mathrm{s})$ & 129.8 & 129.66 & 5.33 (br s) \\
\hline $\mathrm{C}-13$ & 137.0 & & 137.8 & & 139.5 & 139.50 & \\
\hline C-14 & 41.2 & & 41.3 & & 42.9 & 42.59 & \\
\hline $\mathrm{CH}_{2}-15$ & 28.0 & & 28.2 & & 29.7 & 29.63 & $1.83,1.02$ \\
\hline $\mathrm{CH}_{2}-16$ & 25.8 & & 25.7 & & 26.5 & 26.51 & $2.16(\mathrm{td}), 1.63$ \\
\hline C-17 & 47.5 & & 48.8 & & 49.0 & 49.41 & \\
\hline $\mathrm{CH}-18$ & 46.3 & $2.77(\mathrm{~s})$ & 46.4 & $2.65(\mathrm{~s})$ & 54.9 & 54.88 & $2.51(\mathrm{~s})$ \\
\hline C-19 & 72.9 & & 72.9 & & 72.9 & 73.63 & \\
\hline $\mathrm{CH}-20$ & 41.4 & & 41.8 & & 41.3 & 42.87 & 1.36 \\
\hline $\mathrm{CH}_{2}-21$ & 23.6 & & 23.6 & & 27.2 & 27.19 & 1.71 \\
\hline $\mathrm{CH}_{2}-22$ & 30.6 & & 30.8 & & 32.2 & 38.24 & $1.77,1.63$ \\
\hline $\mathrm{CH}_{3}-23$ & 27.8 & $1.10(\mathrm{~s})$ & 27.1 & $0.95(\mathrm{~s})$ & 28.5 & 28.59 & $1.05(\mathrm{~s})$ \\
\hline $\mathrm{CH}_{3}-24$ & 15.6 & $0.90(\mathrm{~s})$ & 15.6 & $0.75(\mathrm{~s})$ & 17.0 & 17.06 & $0.85(\mathrm{~s})$ \\
\hline $\mathrm{CH}_{3}-25$ & 16.2 & $0.85(\mathrm{~s})$ & 14.6 & $0.85(\mathrm{~s})$ & 16.0 & 16.06 & $0.95(\mathrm{~s})$ \\
\hline $\mathrm{CH}_{3}-26$ & 16.8 & $0.71(\mathrm{~s})$ & 16.3 & $0.68(\mathrm{~s})$ & 17.6 & 17.61 & $0.77(\mathrm{~s})$ \\
\hline $\mathrm{CH}_{3}-27$ & 24.0 & $1.20(\mathrm{~s})$ & 22.9 & $1.22(\mathrm{~s})$ & 24.7 & 24.73 & $1.33(\mathrm{~s})$ \\
\hline C-28 & 175.7 & - & 177.1 & - & 178.5 & 178.46 & \\
\hline $\mathrm{CH}_{3}-29$ & 29.9 & $1.30(\mathrm{~s})$ & 28.9 & $1.06(\mathrm{~s})$ & 28.9 & 27.14 & $1.20(\mathrm{~s})$ \\
\hline $\mathrm{CH}_{3}-30$ & 15.2 & $1.00(\mathrm{~d}, 6.0)$ & 14.8 & $0.89(\mathrm{~d}, 5.6)$ & 16.6 & 16.63 & $0.93(\mathrm{~d}, 6.8)$ \\
\hline sugars & \multicolumn{4}{|c|}{ 3-O-Ara } & $3-O-\mathrm{GlcA}$ & & \\
\hline $\mathrm{CH}-1$ & 104.2 & $4.30(\mathrm{~d}, 6.9)$ & 105.6 & $4.19(\mathrm{~d}, 7.2)$ & 106.7 & 107.01 & $4.29(\mathrm{~d}, 7.0)$ \\
\hline $\mathrm{CH}-2$ & 72.9 & & 69.7 & & 73.9 & 72.04 & 3.71 \\
\hline $\mathrm{CH}-3$ ' & 79.8 & & 82.4 & & 77.9 & 83.80 & 3.65 \\
\hline $\mathrm{CH}-4$ & 72.9 & & 68.1 & & 75.5 & 69.46 & 4.03 (br s) \\
\hline $\mathrm{CH}-5$ & - & & - & & 78.3 & - & \\
\hline $\mathrm{CH}_{2}-5$ & 63.0 & & 65.2 & & - & 66.62 & $3.86(\mathrm{dd}), 3.55(\mathrm{~d})$ \\
\hline C-6' & - & & - & & 180.8 & - & \\
\hline $\mathrm{CH}_{2}-6$ & - & & - & & & - & \\
\hline \multicolumn{8}{|c|}{ 3-O-Glc } \\
\hline $\mathrm{CH}-1 "$ & 100.6 & $4.72(\mathrm{~d}, 7.1)$ & 103.9 & $4.45(\mathrm{~d}, 7.8)$ & & 105.30 & $4.56(\mathrm{~d}, 7.3)$ \\
\hline $\mathrm{CH}-2 "$ & 70.0 & & 73.9 & & & 75.25 & 3.31 \\
\hline $\mathrm{CH}-3 "$ & 72.0 & & 76.9 & & & 77.80 & 3.31 \\
\hline $\mathrm{CH}-4 "$ & 68.0 & & 69.8 & & & 71.13 & 3.37 \\
\hline $\mathrm{CH}-5 "$ & 71.9 & & 76.5 & & & 77.56 & 3.49 \\
\hline \multirow[t]{2}{*}{$\mathrm{CH}_{2}-6 "$} & 61.5 & & 61.0 & & & 62.34 & $3.82(\mathrm{dd}), 3.70$ \\
\hline & & & $28-O-\mathrm{Glc}$ & & & & \\
\hline $\mathrm{CH}-1^{\prime \prime}$ & 91.7 & $5.55(\mathrm{~d}, 8.1)$ & 94.4 & $5.25(\mathrm{~d}, 8.2)$ & 95.8 & 95.70 & $5.33(\mathrm{~d}, 8.3)$ \\
\hline CH-2"” & 70.2 & & 72.5 & & 73.9 & 73.78 & 3.33 \\
\hline $\mathrm{CH}-3$ "” & 73.9 & & 77.3 & & 78.6 & 78.45 & 3.35 \\
\hline $\mathrm{CH}-4$ ", & 67.9 & & 70.7 & & 71.1 & 71.05 & 3.37 \\
\hline CH-5"” & 72.4 & & 76.3 & & 78.3 & 78.20 & 3.42 \\
\hline $\mathrm{CH}_{2}-6 "$ & 62.9 & & 61.0 & & 62.4 & 62.39 & $3.82(\mathrm{dd}), 3.70$ \\
\hline $\mathrm{CH}-1$ "', & 99.7 & $4.73(\mathrm{~d}, 7.8)$ & & & & & \\
\hline $\mathrm{CH}-2, "$, & 69.9 & & & & & & \\
\hline $\mathrm{CH}-3, "$, & 72.0 & & & & & & \\
\hline CH-4"”, & 68.0 & & & & & & \\
\hline $\mathrm{CH}-5, "$, & 71.9 & & & & & & \\
\hline $\mathrm{CH}_{2}-6, "$, & 61.5 & & & & & & \\
\hline
\end{tabular}

Mo-1 $=20(R)=$ randiasaponin $\mathrm{III}^{16}=$ ilekudinoside $\mathrm{E}^{15}$ 
in Ilex kudincha ${ }^{15}$ and Randia formosa. ${ }^{16}$ Thus, $\mathbf{4}$ is the epimer of ilekudinoside $\mathrm{E}$ and randiasaponin III.

In relation to $\mathbf{5}$, through comparison of its ${ }^{13} \mathrm{C}-\mathrm{NMR}-\{1 \mathrm{H}\}$ and ${ }^{13} \mathrm{C}$-NMR-DEPT spectra, it was possible to identify the presence of 7 methyl, 10 methylene and 16 methine groups and 8 quaternary carbon atoms. ${ }^{1} \mathrm{H}-\mathrm{NMR}$ joined to ${ }^{13} \mathrm{C}-\mathrm{NMR}$ data indicated the presence of two sugar residues. The later spectrum also evidenced the presence of one glucose residue linked to C-28 via an ester linkage (anomeric carbon at $\left.\delta_{\mathrm{C}} 95.8\right)$ and the presence of glucuronic acid moiety $\left(\delta_{\mathrm{C}}\right.$ 106.7) attached to C-3. Comparison of the NMR data of compound 5 to those of the literature allowed the identification of its aglycone as pomolic acid, one $19 \alpha$-hydroxyursolic acid derivative possessing a $20 R$-configuration. ${ }^{17}$ The $\beta$ configuration for the glucopyranosyl and glucuronopyranosyl units and the $\alpha$ configuration for the arabinopyranosyl residues were inferred from their ${ }^{13} \mathrm{C}$-NMR data and $J$ values. ${ }^{18}$ These data suggested that 5 is the $3 \beta-O-\beta$-D-glucuronopyranosyl$20(R)-19 \alpha$-hydroxyurs-12-en-28-oic acid 28- $O$ - $\beta$-D-glucopyranosyl ester (Figure 1) which was already isolated from Ilex kudincha by Nishimura et al..$^{15}$ as ilekudinoside B.

To the best of our knowledge, the saponins $\mathbf{3}$ and $\mathbf{4}$ reported herein have not been yet described in the literature. Moreover, excepting few reports, ${ }^{8,19}$ the co-occurrence of triterpenes with configuration $20 R$ and $20 S$ is not a common feature to the Ilex species already studied. Indeed, it is possible to differentiate I. chamaedryfolia from other South-American Ilex considering their saponins. ${ }^{8}$

\section{CONCLUSIONS}

Several works have demonstrated that the saponins isolated from leaves of I. paraguariensis (maté) are different from those found in other South-American Ilex species. ${ }^{1,3-6,8}$ The aglycone pattern 19-hydroxyursolic and 29-hydroxyursolic acid found in saponins isolated from South-American Ilex species investigated up to now, allowed to differentiate all this species from I. paraguariensis leaves whose saponins are glycosides of ursolic or oleanolic acid. As suggested by our previous results, ${ }^{8}$ saponin content of South-American Ilex species can be used as a chemotaxonomic tool to the genera. This was confirmed herein considering that saponins so far isolated from I. chamaedryfolia are based on 19-hydroxyursane triterpenes which are different from those presented in the leaves of $I$. paraguariensis.

\section{ACKNOWLEDGEMENTS}

The authors are grateful to M. Sobral (Universidade Federal do Rio Grande do Sul) and S. A. L. Bordignon (Centro Universitário La
Salle, Canoas-RS) for collecting and identifying the plant material and to Unidade de Química de Proteínas e Espectrometria de Massas (Uniprote-MS) do Centro de Biotecnologia/UFRGS for HRMS. This work was supported by the Brazilian agencies: CNPq, CAPES and FAPERGS. The authors are also grateful to the Programa de PósGraduação em Ciências Farmacêuticas/UFRGS (Brazil).

\section{REFERENCES}

1. Schenkel, E. P.; Gosmann, G.; Montanha, J. A.; Heizmann, B. M.; Athayde, M. L.; Taketa, A. T. C.; Pires, V. S.; Guillaume, D.; Cien. Cult. 1997, 49, 359

2. Giberti, G. C.; Dominguezia 1989, 7, 1.

3. Pires, V. S.; Guillaume, D.; Gosmann, G.; Schenkel, E. P.; J. Agric. Food Chem. 1997, 45, 1027.

4. Athayde, M. L.; Schenkel, E. P.; Gnoatto, S. B.; Gosmann, G.; Giberti, G. C.; Guillaume, D.; Acta Farm. Bonaerense 2001, 20, 13.

5. Taketa, A. T. C.; Schlager, T. S.; Guillaume, D.; Gosmann, G.; Schenkel, E. P.; Phytochemistry 2000, 53, 901.

6. Gosmann, G.; Schenkel, E. P.; Seligmann, O.; J. Nat. Prod. 1989, 52, 1367.

7. Athayde M. L.; Schenkel, E. P.; Gosmann, G.; Guillaume, D.; Acta Farm. Bonaerense 1999, 18, 49.

8. Pires, V. S.; Gosmann, G.; Guillaume, D.; Schenkel, E. P.; Nat. Prod. Lett. 2002, 16, 401; Gnoatto, S. C. B.; Bassani, V. L.; Coelho, G. C.; Schenkel, E. P.; Quim. Nova 2007, 30, 304.

9. Edwin, G.; Reitz, P. R. In Flora Ilustrada Catarinense. I Parte; Reitz, P. R., ed.; Herbário Barbosa Rodrigues/CNPq: Itajaí, 1967, cap. Aquifoliáceas.

10. Seo, S.; Tomita, Y.; Tori, K.; Tetrahedron Lett. 1975, $1,7$.

11. The Merck Index: an encyclopedia of chemicals, drugs, and biologicals; Budavari, S., ed.; Merck: Whitehouse Station, 1996, 12 ${ }^{\text {th }}$ ed., p. 1686-7.

12. Hidaka, K.; Ito, M.; Matsuda, Y.; Kohda, H.; Yamasaki, K.; Yamahara, J.; Chisaka, T.; Kawakami, Y.; Sato, T.; Kagei, K.; Chem. Pharm. Bull. 1987, 35, 524

13. Wenjuan, Q.; Xiue, W.; Junjie, Z.; Fukuyama, Y.; Yamada, T.; Nakagawa, K.; Phytochemistry 1986, 25, 913.

14. Massiot, G.; Lavaud, C.; Binst, V. G.; Miller, P. F. S.; Fales, H. M.; J. Chem. Soc.: Perkin Trans. I 1988, 3071.

15. Nishimura, K.; Miyase, T.; Nogushi, H.; J. Nat. Prod. 1999, 62, 1128.

16. Sahpaz, S.; Gupta, M. P.; Hostettmann, K.; Phytochemistry 2000, 54, 77.

17. Kakuno, T.; Yoshikawa, K.; Arihara, S.; Phytochemistry 1992, 31, 2809.

18. Agrawal, P. K.; Phytochemistry 1992, 31, 3307.

19. Ouyang, M. A.; Liu, Y. Q.; Wang, H. Q.; Yang, C. R.; Phytochemistry 1998, 49, 2483. 